\title{
Isosulfan Blue and Anaphylaxis
}

\author{
Abin Sajan, MD, ${ }^{1,2}$ Daniel W. Griepp, BE, ${ }^{1,3}$ Hazim Hakmi, MD, ${ }^{1}$ Amir H. Sohail, MD, ${ }^{1}$ Jackson Hunt, MD, ${ }^{1}$ \\ Michelle Wolf, PA-C, ${ }^{1}$ Zhanna Logman, MD ${ }^{1}$ \\ ${ }^{1}$ Department of Surgery, NYU Langone Hospital-Long Island, Mineola, NY ${ }^{2}$ Department of Radiology, Columbia University Irving Medical \\ Center, New York, NY ${ }^{3}$ New York Institute of Technology College of Osteopathic Medicine, Old Westbury, NY
}

Background: Isosulfan blue dye, or Lymphazurin, is commonly used for sentinel lymph node biopsy during operative procedures for patients with breast cancer. Allergic reactions to Lymphazurin have been reported, ranging from mild dermatologic reactions to severe anaphylaxis.

Case Series: We report 2 patients who experienced allergic reaction to Lymphazurin while admitted to our service. We also conducted a literature search for similar cases using national databases. Included studies were limited to retrospective studies, case series, or case reports. Patient characteristics, reaction observed, and hospital course were extracted. Of the patients we report, both had grade 3 anaphylactic reactions requiring vasopressors to achieve hemodynamic stability. One patient required intensive care unit monitoring for 18 hours, and the other required overnight monitoring in the postanesthesia care unit. The literature revealed 29 studies reporting 108 patients with confirmed allergic reactions to Lymphazurin. Including the 2 patients in this series (total study $n=110)$, most reactions were grade $3(57 / 110,51.8 \%)$, followed by grade $1(40 / 110,36.4 \%)$ and grade $2(13 / 110,11.8 \%)$. Among the patients who had individual hospital course reported $(n=34), 23$ patients required admission to the surgical intensive care unit. Of studies that reported cancellation or progression of surgery after the reaction, the surgical procedure was canceled for 12 of 26 patients (46.1\%).

Conclusion: Although severe anaphylactic reactions are more commonly reported, mild reactions occur more frequently but are likely underreported. Although no fatalities were reported in the cases included in this review, anaphylactic reactions to Lymphazurin pose significant risks. Operating room personnel should be familiar with potential reactions to recognize and treat them early.

Keywords: Anaphylaxis, contrast, isosulfan blue

Address correspondence to Zhanna Logman, MD, Department of Surgery, NYU Langone Hospital-Long Island, 259 1st St., Mineola, NY 11501. Tel: (516) 222-7818. Email: zhanna.logman@nyulangone.org

\section{INTRODUCTION}

Isosulfan blue dye or Lymphazurin, an isomer of patent blue dye, is an integral component of lymphangiography in sentinel lymph node biopsy (SLNB). ${ }^{1-3}$ Typically injected preprocedurally, isosulfan blue dye is selectively absorbed by the lymphatics and aids in visualizing the lymphatic channels. Allergic reactions to isosulfan blue dye have been previously reported, with an incidence of $0.6 \%$ to $2.5 \% .^{4,5}$ Allergic reactions can range from localized skin changes to lifethreatening multiorgan failure.,7 The prevalence of SLNB with isosulfan blue dye has extended outside breast cancer, with new indications in melanoma and neoplasms of the bladder, cervix, and uterus. ${ }^{2}$ As the use of isosulfan blue dye has increased, reports of associated adverse reactions have increased. However, synthesis of previously reported allergic reactions to isosulfan blue dye is limited, particularly with regard to the effect on hospital course, such as cancellation of surgery or time spent in the intensive care unit.
We report 2 cases of severe anaphylaxis to isosulfan blue dye and present a review of reported cases of allergic reactions to isosulfan blue dye.

\section{CASE SERIES \\ Case 1}

A 46-year-old female with high-grade comedo necrosis ductal carcinoma in situ of the left breast presented for elective lumpectomy and SLNB. She had a history of hypertension and ovarian cysts with no previously reported allergic reactions. On the day of the surgery, $5 \mathrm{~mL}$ Lymphazurin was injected intradermally into the breast tissue surrounding the site of carcinoma. The surgical site was prepped with Betadine (povidone-iodine), and anesthesia was induced with $100 \mu \mathrm{g}$ intramuscular fentanyl, 2 mg intravenous midazolam, and $200 \mathrm{mg}$ propofol. A laryngeal mask airway (LMA) was inserted, and the patient was administered $1 \mathrm{~g}$ cefazolin and $30 \mathrm{mg}$ lidocaine $\mathrm{HCl} 1 \%$ for local anesthesia. 
Table 1. Pharmacologic Agents Administered

\begin{tabular}{|c|c|c|c|}
\hline Case 1 & Quantity & Case 2 & Quantity \\
\hline Midazolam 2 mg IV & 2 & Midazolam 2 mg IV & 2 \\
\hline Fentanyl $100 \mu \mathrm{g}$ IM & 1 & Fentanyl $50 \mu \mathrm{g}$ IV & 1 \\
\hline Lidocaine $\mathrm{HCl} 1 \% 30 \mathrm{mg}$ subq & 1 & Lidocaine $\mathrm{HCl} 1 \% 40 \mathrm{mg}$ subq & 1 \\
\hline Propofol 200 mg IV & 1 & Propofol $200 \mathrm{mg}$ IV & 1 \\
\hline Cefazolin $1 \mathrm{~g} \mathrm{IV}$ & 1 & & \\
\hline Phenylephrine $100 \mu \mathrm{g} \mathrm{IV}$ & 2 & Phenylephrine $200 \mu \mathrm{g}$ IV & 4 \\
\hline Hydrocortisone $100 \mathrm{mg} \mathrm{IV}$ & 1 & Hydrocortisone $100 \mathrm{mg}$ IV & 1 \\
\hline Diphenhydramine $50 \mathrm{mg}$ IV & 1 & Diphenhydramine $50 \mathrm{mg}$ IV & 1 \\
\hline Ephedrine $10 \mathrm{mg} \mathrm{IV}$ & 2 & Ephedrine $20 \mathrm{mg}$ IV & 2 \\
\hline Epinephrine $100 \mu \mathrm{g} \mathrm{IV}$ & 3 & Epinephrine $30 \mu \mathrm{g} \mathrm{IV}$ & 3 \\
\hline
\end{tabular}

$\mathrm{IM}$, intramuscular; IV, intravenous; subq, subcutaneous.

Five minutes after administering Lymphazurin and before the first incision, the patient became tachycardic to the $120 / \mathrm{min}$ range, and systolic blood pressure dropped to $75 \mathrm{mmHg}$. Shortly after, the patient appeared flushed with swollen distal extremities, suggestive of an anaphylactic reaction. Her systolic pressure was mildly responsive to 2 doses of phenylephrine $100 \mu \mathrm{g}$ and reached as low as $60 \mathrm{mmHg}$ approximately 10 minutes after the initial reaction. She was given $100 \mu \mathrm{g}$ epinephrine, as well as injections of $50 \mathrm{mg}$ diphenhydramine and $100 \mathrm{mg}$ hydrocortisone. Given her compromised hemodynamic status, the patient was successfully intubated with an endotracheal tube, and the planned procedure was canceled. Table 1 summarizes the pharmacologic agents administered, including those given after the decision was made to cancel the surgery.

The patient was transferred to the surgical intensive care unit (SICU) and closely monitored. She remained intubated overnight and was weaned off the vasopressors by the morning. On hospital day 1, she was extubated and downgraded without issues. She was discharged on hospital day 2 with $20 \mathrm{mg}$ famotidine and a $20 \mathrm{mg}$ hydrocortisone taper. Despite multiple attempts to contact the patient, she was lost to follow-up and did not undergo allergy testing.

\section{Case 2}

A 51-year-old female with high-grade comedo necrosis ductal carcinoma in situ of the right breast presented for elective excision of right breast calcification and SLNB. She had a history of allergic reaction (mild pruritus) to apples, peaches, plums, and cherries. On the day of surgery, $5 \mathrm{~mL}$ Lymphazurin was injected, and she was prepped with Betadine (povidone-iodine). An LMA was inserted after administering $2 \mathrm{mg}$ midazolam, $50 \mu \mathrm{g}$ fentanyl, and $200 \mathrm{mg}$ propofol.

After local anesthesia (40 mg lidocaine $\mathrm{HCl} 1 \%$ ) was administered, the SLNB was successfully completed in 15 minutes. Approximately 25 minutes after injecting isosulfan blue dye during the mass excision portion of the case, the patient's blood pressure dropped to $50 / 30 \mathrm{mmHg}$ with associated bradycardia in the $60 / \mathrm{min}$ range. Anaphylactic reaction was suspected given the patient's facial flushing and swelling of the upper extremities. During the next 30 minutes, the patient received multiple vasopressor infusions, including phenylephrine $200 \mu \mathrm{g}$, epinephrine $30 \mu \mathrm{g}$, and ephedrine $20 \mathrm{mg}$. The patient also required administration of additional pharmacologic agents that are listed in Table 1. The patient was intubated with an endotracheal tube because of prolonged hemodynamic instability. Approximately 90 minutes after the initial injection, systolic pressure sustained in the $100 \mathrm{mmHg}$ range, and the case was completed successfully. The patient was transferred to the postanesthesia care unit (PACU) and monitored overnight. She was stable overnight and discharged the following day from the PACU with no complaints. Outpatient workup isolated the allergic reaction to isosulfan blue dye and eliminated allergies to any anesthetic and analgesic agents. Table 2 summarizes the outpatient workup by the allergist confirming allergy to isosulfan blue dye.

\section{DISCUSSION}

Reports of allergic reactions to patent blue dye (parent molecule of isosulfan blue dye) trace back to 1966 when Kopp described 2 cases of anaphylaxis during lymphangiography. ${ }^{8}$ The US Food and Drug Administration approved isosulfan blue dye for lymphatic mapping in 1982, and a case report in the same year by Rubis et al was the first to report an allergic reaction specific to Lymphazurin. ${ }^{9}$ The reported cases have increased over the years, ranging from self-resolving erythema or urticaria to complicated cases of cardiovascular or respiratory collapse requiring SICU monitoring. ${ }^{5,10,11}$ The current estimated incidence of adverse reactions to isosulfan blue dye is as high as $2.5 \%$. $^{4,11}$

The pathophysiology of adverse reactions to isosulfan blue dye is not well understood. The anaphylactic reaction involves development of immunoglobulin $E$ antibodies against foreign material. ${ }^{10}$ The antigen causes crosslinking and degranulation of mast cells, resulting in the release of histamine and other vasoactive mediators of anaphylaxis. ${ }^{4}$ Other postulated mechanisms include disorders in the arachidonic acid metabolism, direct activation of mast cells, and idiopathic anaphylaxis. ${ }^{12,13}$

Montgomery et al classified the range of adverse reactions secondary to isosulfan blue dye into 3 grades. ${ }^{14}$ Grade 1 
Table 2. Outpatient Allergy Skin Testing Results for Case 2

\begin{tabular}{|c|c|c|c|}
\hline Product & Prick, mm & Intradermal, mm & Result \\
\hline Histamine & 4,8 & 10,21 & Positive control \\
\hline Diluent control & 0,0 & 0,0 & Negative control \\
\hline Midazolam, $0.5 \mathrm{mg} / \mathrm{mL}$ & 0,0 & & Negative \\
\hline Midazolam, 1:100 & & 0,0 & Negative \\
\hline Midazolam, 1:10 & & 0,0 & Negative \\
\hline Fentanyl, $0.05 \mathrm{mg} / \mathrm{mL}$ & 0,0 & & Negative \\
\hline Fentanyl, 1:1,000 & & 0,0 & Negative \\
\hline Fentanyl, 1:100 & & 0,0 & Negative \\
\hline Propofol, 10 mg/mL & 0,0 & & Negative \\
\hline Propofol, 1:100 & & 0,0 & Negative \\
\hline Propofol, 1:10 & & 0,0 & Negative \\
\hline Cefazolin, $330 \mathrm{mg} / \mathrm{mL}$ & 0,0 & & Negative \\
\hline Cefazolin, 1:100 & & 0,0 & Negative \\
\hline Cefazolin, 1:10 & & 0,0 & Negative \\
\hline PRE-PEN (benzylpenicilloyl polylysine: 10,000 U/mL) & 0,0 & 0,0 & Negative \\
\hline Penicillin G, (benzylpenicillin: 10,000 U/mL) & 0,0 & 0,0 & Negative \\
\hline Lidocaine $2 \%, 20 \mathrm{mg} / \mathrm{mL}$ & 0,0 & & Negative \\
\hline Lidocaine, 1:100 & & 0,0 & Negative \\
\hline a Isosulfan blue $1 \%, 10 \mathrm{mg} / \mathrm{mL}$ & 6,8 & & Positive \\
\hline${ }^{a}$ Isosulfan blue $1 \%, 10 \mathrm{mg} / \mathrm{mL}$ & 5,5 & & Positive \\
\hline Isosulfan blue, 1:10,000 & 0,0 & & Negative \\
\hline Isosulfan blue, 1:1,000 & 11,22 & & Positive \\
\hline
\end{tabular}

Note: Table shows negative skin testing to PRE-PEN and Penicillin G via intradermal and percutaneous methods with appropriate positive and negative controls. The patient tested negative to midazolam, fentanyl, propofol, cefazolin, and lidocaine but positive to isosulfan blue.

${ }^{\text {aTest }}$ was repeated to confirm reaction to isosulfan blue.

is the simplest reaction and includes urticaria, pruritus, and at times, a rash with or without hives. Grade 2 involves transient hypotension not requiring vasopressors, and grade 3 involves hypotension requiring vasopressors. In the present case series, both patients had grade 3 reactions that required vasopressors and close hemodynamic monitoring.

Review of the literature using national databases (Medline, Embase, and Cochrane) revealed 29 studies reporting 108 patients who had confirmed reported cases of adverse events to isosulfan blue dye. ${ }^{1-7,10,11,14-33}$ Tables 3 and 4 provide a summary of characteristics, reactions observed, and clinical course of the patients in studies included in this review. Including the 2 patients in the present series $(n=110)$, most patients had a grade $3(57 / 110,51.8 \%)$ reaction, followed by grade $1(40 / 110,36.4 \%)$ and grade $2(13 / 110$, $11.8 \%)$. Among the patients for whom hospital course was reported $(n=34), 23$ known patients were admitted to the SICU. Additionally, the planned surgery was canceled for 12 of 26 patients for whom these data were available, but the status of the planned procedure was unknown for 84 patients. In our series, the first patient required SICU monitoring and was discharged on the second hospital day, while the second patient had a less severe reaction, recovered more favorably, was able to complete the planned surgery, and only required overnight PACU monitoring prior to discharge.

Given the potential for complex pharmacologic interactions among antibiotics and anesthetic agents administered during surgical procedures, isolating the reaction can be difficult. ${ }^{15}$ Although the temporal relationship provides a challenge, the rate of allergic reactions to antibiotics and anesthetic agents is considered significantly smaller than the rate of allergic reactions to isosulfan blue dye. For example, cefazolin allergy has been reported in 1/17,000 (0.006\%) cases compared to the reported $0.6 \%$ to $2.5 \%$ of isosulfan blue dye allergies. ${ }^{4,5,11}$ Additionally, most patients have been previously exposed to beta-lactam antibiotics. ${ }^{4}$ One patient in our series underwent outpatient allergy profile testing to rule out reactions to the antibiotics and anesthetic agents used during surgery (Table 2).

Severe allergic reactions to isosulfan blue dye can extend hospital stay, and the associated intensive care poses a significant financial and mental burden on patients. Studies have previously explored the alternatives to isosulfan blue dye, such as fluorescent dye or methylene blue; however, similar reactions have been reported. ${ }^{34}$ Skin testing prior to the procedure or preprocedural steroids or antihistamines are other options to avoid anaphylaxis in this setting, especially in high-risk patients with similar allergies or history 
Table 3. Characteristics of Studies Included in the Review

\begin{tabular}{|c|c|c|c|c|c|c|c|c|c|}
\hline Study & $\mathbf{N}$ & $\begin{array}{l}\text { Age, } \\
\text { years, } \\
\text { Sex }\end{array}$ & Dose & Grade 1 & Grade 2 & Grade 3 & $\begin{array}{l}\text { Time From } \\
\text { Administration } \\
\text { to Reaction }\end{array}$ & $\begin{array}{l}\text { Surgery } \\
\text { Canceled }\end{array}$ & Time in SICU \\
\hline Longnecker et al, $1985^{17}$ & 1 & $\mathrm{~N} / \mathrm{R}$ & $N / R$ & & & 1 & $1 \mathrm{~min}$ & $\mathrm{~N} / \mathrm{R}$ & $24 \mathrm{~h}$ \\
\hline \multirow[t]{3}{*}{ Leong et al, $2000^{18}$} & 3 & $38, M$ & $4.8 \mathrm{~mL}$ & & & 1 & $30 \min$ & Yes & $36 \mathrm{~h}$ \\
\hline & & $66, F$ & $4.7 \mathrm{~mL}$ & & & 1 & $15 \min$ & No & None \\
\hline & & $81, F$ & $4.8 \mathrm{~mL}$ & & & 1 & $15 \mathrm{~min}$ & Yes & $48 \mathrm{~h}$ \\
\hline Lyew et al, $2000^{5}$ & 1 & $48, F$ & $5 \mathrm{~mL}$ & & & 1 & $5 \mathrm{~min}$ & No & $18 \mathrm{~h}$ \\
\hline \multirow[t]{5}{*}{ Cimmino et al, $2001^{11}$} & 5 & $22, F$ & $3 \mathrm{~mL}$ & & & 1 & $10 \min$ & $\mathrm{N} / \mathrm{R}$ & Yes, time N/R \\
\hline & & $72, \mathrm{M}$ & $3 \mathrm{~mL}$ & & & 1 & $8 \min$ & $\mathrm{N} / \mathrm{R}$ & Yes, time N/R \\
\hline & & $50, F$ & $3 \mathrm{~mL}$ & & & 1 & $40 \mathrm{~min}$ & $\mathrm{~N} / \mathrm{R}$ & $\mathrm{N} / \mathrm{R}$ \\
\hline & & $47, F$ & $5 \mathrm{~mL}$ & & 1 & & $30-40 \mathrm{~min}$ & $\mathrm{~N} / \mathrm{R}$ & $\mathrm{N} / \mathrm{R}$ \\
\hline & & $47, F$ & $5 \mathrm{~mL}$ & & 1 & & $30-40 \mathrm{~min}$ & $\mathrm{~N} / \mathrm{R}$ & $\mathrm{N} / \mathrm{R}$ \\
\hline \multirow[t]{7}{*}{ Albo et al, $2001^{4}$} & 7 & $75, F$ & $5 \mathrm{~mL}$ & & & 1 & $20 \min$ & $\mathrm{N} / \mathrm{R}$ & $48 \mathrm{~h}$ \\
\hline & & $75, \mathrm{~F}$ & $5 \mathrm{~mL}$ & & & 1 & $15 \mathrm{~min}$ & $\mathrm{~N} / \mathrm{R}$ & $24 \mathrm{~h}$ \\
\hline & & $50, F$ & $5 \mathrm{~mL}$ & & & 1 & $15 \min$ & $\mathrm{N} / \mathrm{R}$ & $24 \mathrm{~h}$ \\
\hline & & $47, F$ & $5 \mathrm{~mL}$ & & & 1 & $15 \mathrm{~min}$ & $\mathrm{~N} / \mathrm{R}$ & $24 \mathrm{~h}$ \\
\hline & & $65, \mathrm{~F}$ & $5 \mathrm{~mL}$ & & & 1 & $30 \mathrm{~min}$ & $\mathrm{~N} / \mathrm{R}$ & $48 \mathrm{~h}$ \\
\hline & & $53, F$ & $5 \mathrm{~mL}$ & & & 1 & $20 \mathrm{~min}$ & $N / R$ & $72 \mathrm{~h}$ \\
\hline & & $53, F$ & $5 \mathrm{~mL}$ & & & 1 & $30 \mathrm{~min}$ & $\mathrm{~N} / \mathrm{R}$ & $24 \mathrm{~h}$ \\
\hline Kuerer et al, $2001^{19}$ & 1 & $75, F$ & $5 \mathrm{~mL}$ & & & 1 & $40 \mathrm{~min}$ & No & $\mathrm{N} / \mathrm{R}$ \\
\hline Krouse and Schwarz, $2001^{20}$ & 1 & $63, F$ & $4 \mathrm{~mL}$ & & 1 & & $\mathrm{~N} / \mathrm{R}$ & No & $\mathrm{N} / \mathrm{R}$ \\
\hline \multirow[t]{2}{*}{ Sadiq et al, $2001^{21}$} & 2 & $52, \mathrm{~F}$ & $2 \mathrm{~mL}$ & & 1 & & $45 \mathrm{~min}$ & No & None \\
\hline & & $57, F$ & $2 \mathrm{~mL}$ & & 1 & & $25 \mathrm{~min}$ & Yes & None \\
\hline Kuerer et al, $2001^{22}$ & 1 & $52, \mathrm{~F}$ & $5 \mathrm{~mL}$ & & & 1 & $\mathrm{~N} / \mathrm{R}$ & Yes & $\mathrm{N} / \mathrm{R}$ \\
\hline \multirow[t]{2}{*}{ Giménez et al, $2001^{23}$} & 2 & $48, F$ & $4 \mathrm{~mL}$ & & & 1 & $5 \mathrm{~min}$ & No & $\mathrm{N} / \mathrm{R}$ \\
\hline & & $60, F$ & $2 \mathrm{~mL}$ & & & 1 & $5 \mathrm{~min}$ & No & None \\
\hline \multirow[t]{2}{*}{ Laurie et al, $2002^{10}$} & 2 & $60, F$ & $5 \mathrm{~mL}$ & & & 1 & $5 \min$ & Yes & $48 \mathrm{~h}$ \\
\hline & & $62, \mathrm{~F}$ & $5 \mathrm{~mL}$ & & & 1 & $40 \mathrm{~min}$ & Yes & None \\
\hline Montgomery et al, $2002^{14}$ & 39 & $\mathrm{~N} / \mathrm{R}$ & $\mathrm{N} / \mathrm{R}$ & 27 & 3 & 9 & $44 \min$ (mean) & $\mathrm{N} / \mathrm{R}$ & $\mathrm{N} / \mathrm{R}$ \\
\hline Efron et al, $2002^{24}$ & 1 & $54, \mathrm{~F}$ & $5 \mathrm{~mL}$ & & & 1 & $10 \min$ & No & $24 \mathrm{~h}$ \\
\hline Stefanutto et al, $2002^{25}$ & 1 & $\mathrm{~N} / \mathrm{R}$ & $\mathrm{N} / \mathrm{R}$ & & & 1 & $\mathrm{~N} / \mathrm{R}$ & $\mathrm{N} / \mathrm{R}$ & $\mathrm{N} / \mathrm{R}$ \\
\hline Sprung et al, $2003^{26}$ & 1 & $53, F$ & $4 \mathrm{~mL}$ & & & 1 & $1 \mathrm{~min}$ & Yes & $\mathrm{N} / \mathrm{R}$ \\
\hline Raut et al, $2004^{27}$ & 3 & $\mathrm{~N} / \mathrm{R}$ & $5 \mathrm{~mL}$ & 3 & & & $\mathrm{~N} / \mathrm{R}$ & $\mathrm{N} / \mathrm{R}$ & $\mathrm{N} / \mathrm{R}$ \\
\hline Sandhu et al, $2005^{6}$ & 1 & $45, F$ & $5 \mathrm{~mL}$ & & & 1 & $10 \mathrm{~min}$ & Yes & $48 \mathrm{~h}$ \\
\hline \multirow[t]{4}{*}{ Raut et al, $2005^{15}$} & 4 & $73, F$ & $5 \mathrm{~mL}$ & 1 & & & $105 \min$ & $\mathrm{N} / \mathrm{R}$ & None \\
\hline & & $62, \mathrm{~F}$ & $5 \mathrm{~mL}$ & 1 & & & $45 \mathrm{~min}$ & $\mathrm{~N} / \mathrm{R}$ & None \\
\hline & & $53, \mathrm{~F}$ & $5 \mathrm{~mL}$ & 1 & & & $75 \mathrm{~min}$ & $\mathrm{~N} / \mathrm{R}$ & None \\
\hline & & $58, F$ & $5 \mathrm{~mL}$ & 1 & & & $10 \mathrm{~min}$ & $\mathrm{~N} / \mathrm{R}$ & None \\
\hline Amr et al, $2005^{16}$ & 7 & $\mathrm{~N} / \mathrm{R}$ & $\mathrm{N} / \mathrm{R}$ & 6 & & 1 & $\mathrm{~N} / \mathrm{R}$ & $\mathrm{N} / \mathrm{R}$ & $\mathrm{N} / \mathrm{R}$ \\
\hline Komenaka et al, $2005^{28}$ & 3 & $\mathrm{~N} / \mathrm{R}$ & $\mathrm{N} / \mathrm{R}$ & & 3 & & $23 \min ($ mean) & $\mathrm{N} / \mathrm{R}$ & $\mathrm{N} / \mathrm{R}$ \\
\hline Saft and Sarap, $2007^{29}$ & 1 & $54, \mathrm{~F}$ & $5 \mathrm{~mL}$ & & & 1 & $20 \mathrm{~min}$ & Yes & $\mathrm{N} / \mathrm{R}$ \\
\hline \multirow[t]{2}{*}{ Kaufman et al, $2008^{2}$} & 2 & $62, F$ & $5 \mathrm{~mL}$ & & & 1 & $30 \mathrm{~min}$ & $\mathrm{~N} / \mathrm{R}$ & $24 \mathrm{~h}$ \\
\hline & & $77, M$ & $1.8 \mathrm{~mL}$ & & & 1 & $1 \mathrm{~min}$ & $\mathrm{~N} / \mathrm{R}$ & $24 \mathrm{~h}$ \\
\hline Liang and Carson, $2008^{7}$ & 1 & $48, F$ & $5 \mathrm{~mL}$ & & & 1 & $15 \mathrm{~min}$ & Yes & $36 \mathrm{~h}$ \\
\hline O'Sullivan and Morrow, $2008^{30}$ & 1 & $77, \mathrm{~F}$ & $8 \mathrm{~mL}$ & & 1 & & $\mathrm{~N} / \mathrm{A}$ & No & None \\
\hline Cinar et al, $2012^{31}$ & 1 & $65, \mathrm{~F}$ & $5 \mathrm{~mL}$ & & & 1 & $30 \mathrm{sec}$ & No & $2 \mathrm{~h}$ \\
\hline
\end{tabular}


Table 3. Continued

\begin{tabular}{|c|c|c|c|c|c|c|c|c|c|}
\hline Study & $\mathbf{N}$ & $\begin{array}{l}\text { Age, } \\
\text { years, } \\
\text { Sex }\end{array}$ & Dose & Grade 1 & Grade 2 & Grade 3 & $\begin{array}{l}\text { Time From } \\
\text { Administration } \\
\text { to Reaction }\end{array}$ & $\begin{array}{l}\text { Surgery } \\
\text { Canceled }\end{array}$ & Time in SICU \\
\hline \multirow[t]{2}{*}{ Haque and Nossaman, $2012^{1}$} & 2 & $83, F$ & $4 \mathrm{~mL}$ & & 1 & & $\mathrm{~N} / \mathrm{R}$ & No & $\mathrm{N} / \mathrm{R}$ \\
\hline & & $62, F$ & $5 \mathrm{~mL}$ & & & 1 & Within minutes & No & $\mathrm{N} / \mathrm{R}$ \\
\hline Reed et al, $2014^{32}$ & 1 & $44, F$ & $\mathrm{~N} / \mathrm{R}$ & & & 1 & $20 \mathrm{~min}$ & No & $N / R$ \\
\hline Ortiz et al, $2015^{33}$ & 1 & $82, F$ & $1 \mathrm{~mL}$ & & & 1 & $15 \mathrm{~min}$ & Yes & $48 \mathrm{~h}$ \\
\hline Wang et al, $2018^{3}$ & 12 & $N / R$ & $\mathrm{~N} / \mathrm{R}$ & & & 12 & $N / R$ & $N / R$ & Yes, time N/R \\
\hline \multirow[t]{2}{*}{ Present Study } & 2 & $46, F$ & $5 \mathrm{~mL}$ & & & 1 & $5 \mathrm{~min}$ & Yes & $18 \mathrm{~h}$ \\
\hline & & $51, F$ & $5 \mathrm{~mL}$ & & & 1 & $25 \mathrm{~min}$ & No & None \\
\hline
\end{tabular}

$\mathrm{N} / \mathrm{R}$, not reported; SICU, surgical intensive care unit.

of asthma. The benefits of these interventions should be weighed against risks or health care costs through future prospective studies.

The true incidence of isosulfan blue dye allergic reaction is likely higher than the reported $0.6 \%$ to $2.5 \%$. Despite the range of allergic reaction-from skin changes to

Table 4. Summary of Clinical Course of Patients Including the Present Series

\begin{tabular}{|c|c|}
\hline Variable & Value \\
\hline \multicolumn{2}{|l|}{ Demographics } \\
\hline Total patients, $\mathrm{n}$ & 110 \\
\hline Age, years, mean (range); $n=44$ & $58.3(22-83)$ \\
\hline Age not available, $\mathrm{n}(\%)$ & $66 / 110(60)$ \\
\hline Male, n (\%) & $3 / 44(6.8)$ \\
\hline Female, n (\%) & $41 / 44(93.2)$ \\
\hline \multicolumn{2}{|l|}{ Reaction, n (\%) } \\
\hline $\begin{array}{l}\text { Grade } 1-\text { Generalized swelling, urticaria, } \\
\text { mild rash }\end{array}$ & $40 / 110(36.4)$ \\
\hline $\begin{array}{l}\text { Grade } 2 \text {-Hypotension, vasopressors not } \\
\text { given }\end{array}$ & $13 / 110(11.8)$ \\
\hline Grade 3-Hypotension, vasopressors given & $57 / 110(51.8)$ \\
\hline $\begin{array}{l}\text { Dosage of isosulfan blue, } \mathrm{mL} \text {, median } \\
\quad \text { (range); } \mathrm{n}=44\end{array}$ & $5(1.0-8.0)$ \\
\hline $\begin{array}{l}\text { Administration to reaction time, min, mean } \\
\quad \text { (range); } \mathrm{n}=42\end{array}$ & $23.28(0.5-105)$ \\
\hline \multicolumn{2}{|l|}{ Surgery status, $n(\%) ; n=26$} \\
\hline Canceled & $12 / 26(46.1)$ \\
\hline Not canceled & $14 / 26(53.8)$ \\
\hline Not available & $84 / 110(76.4)$ \\
\hline \multicolumn{2}{|l|}{ Surgical intensive care unit admission; $\mathrm{n}=34$} \\
\hline Yes, n (\%) & $23 / 34(67.6)$ \\
\hline Time in intensive care, $\mathrm{h}$, mean (range) & $33.1(2-72)$ \\
\hline No, n (\%) & $11 / 34(32.4)$ \\
\hline Not available, $\mathrm{n}(\%)$ & $76 / 110(69.1)$ \\
\hline Death & None \\
\hline
\end{tabular}

anaphylaxis - the literature principally reports anaphylaxistype reactions requiring SICU level of care. Selective reporting of more severe reactions introduces selection bias as the patients with the most severe reactions who warrant higher levels of care are more likely to be reported than patients with less severe reactions. Of the studies included in this review, 19 of 29 studies reported only patients who had experienced grade 3 reactions. The true incidence of total isosulfan blue dye allergic reaction (regardless of grade) is likely higher than the cases identified in the literature would suggest; the percentage of anaphylaxis/shock grade 3 among all patients with isosulfan blue dye allergy likely remains low.

\section{CONCLUSION}

The use of isosulfan blue dye is a valuable technique in lymph node biopsy; however, isosulfan blue dye is associated with anaphylactic reactions and the consequences may be serious in some cases, as summarized in this review. These cases underscore the importance for operating room personnel to be familiar with such potential reactions so they can recognize and effectively treat them early in acute care settings.

\section{ACKNOWLEDGMENTS}

The authors have no financial or proprietary interest in the subject matter of this article.

\section{REFERENCES}

1. Haque SH, Nossaman BD. Dyed but not dead. Ochsner J. 2012;12(2):135-140.

2. Kaufman G, Guth AA, Pachter HL, Roses DF. A cautionary tale: anaphylaxis to isosulfan blue dye after 12 years and 3339 cases of lymphatic mapping. Am Surg. 2008;74(2):152-155.

3. Wang T, Xu D, Liao Z. Anaphylactic reactions to isosulfan blue dye during sentinel lymph node biopsy for breast cancer. J Curr Surg. 2018;8(3-4):32-34. doi: 10.14740/jcs365w

4. Albo D, Wayne JD, Hunt KK, et al. Anaphylactic reactions to isosulfan blue dye during sentinel lymph node biopsy for breast cancer. Am J Surg. 2001;182(4):393-398. doi: 10.1016/s0002-9610(01)00734-6

5. Lyew MA, Gamblin TC, Ayoub M. Systemic anaphylaxis associated with intramammary isosulfan blue injection used for sentinel node detection under general anesthesia. Anesthesiology. 2000;93(4):1145-1146. doi: 10.1097/00000542-200010000-00041 
6. Sandhu S, Farag E, Argalious M. Anaphylaxis to isosulfan blue dye during sentinel lymph node biopsy. J Clin Anesth. 2005;17(8):633-635. doi: 10.1016/j.jclinane.2005.03.006

7. Liang MI, Carson WE III. Biphasic anaphylactic reaction to blue dye during sentinel lymph node biopsy. World J Surg Oncol. 2008;6:79. doi: 10.1186/1477-7819-6-79

8. Kopp WL. Anaphylaxis from alphazurine $2 \mathrm{G}$ during lymphography. JAMA. 1966;198(6):668-669.

9. Rubis PJ, Tisnado J, Hirsch Jl, Capehart J. Intraoperative identification of chylous fistulas using iso-sulphan blue dye. AJR Am J Roentgenol. 1982;139(1):186-187. doi: 10.2214/ajr.139.1.186

10. Laurie SA, Khan DA, Gruchalla RS, Peters G. Anaphylaxis to isosulfan blue. Ann Allergy Asthma Immunol. 2002;88(1):64-66. doi: 10.1016/S1081-1206(10)63595-8

11. Cimmino VM, Brown AC, Szocik JF, et al. Allergic reactions to isosulfan blue during sentinel node biopsy-a common event. Surgery. 2001;130(3):439-442. doi: 10.1067/msy.2001.116407

12. Peavy RD, Metcalfe DD. Understanding the mechanisms of anaphylaxis. Curr Opin Allergy Clin Immunol. 2008;8(4):310-315. doi: 10.1097/ACl.0b013e3283036a90

13. Metcalfe DD, Peavy RD, Gilfillan AM. Mechanisms of mast cell signaling in anaphylaxis. J Allergy Clin Immunol. 2009;124(4):639-646; quiz 647-648. doi: 10.1016/j.jaci.2009.08.035

14. Montgomery LL, Thorne AC, Van Zee KJ, et al. Isosulfan blue dye reactions during sentinel lymph node mapping for breast cancer. Anesth Analg. 2002;95(2):385-388. doi: 10.1097/00000539-200208000-00026

15. Raut CP, Hunt KK, Akins JS, et al. Incidence of anaphylactoid reactions to isosulfan blue dye during breast carcinoma lymphatic mapping in patients treated with preoperative prophylaxis: results of a surgical prospective clinical practice protocol. Cancer. 2005;104(4):692-699. doi: 10.1002/cncr.21226

16. Amr D, Broderick-Villa G, Haigh PI, Guenther JM, DiFronzo LA. Adverse drug reactions during lymphatic mapping and sentinel lymph node biopsy for solid neoplasms. Am Surg. 2005;71(9):720-724.

17. Longnecker SM, Guzzardo MM, Van Voris LP. Life-threatening anaphylaxis following subcutaneous administration of isosulfan blue 1\%. Clin Pharm. 1985;4(2):219-221.

18. Leong SP, Donegan E, Heffernon W, Dean S, Katz JA. Adverse reactions to isosulfan blue during selective sentinel lymph node dissection in melanoma. Ann Surg Oncol. 2000;7(5):361-366. doi: 10.1007/s10434-000-0361-x

19. Kuerer HM, Hunt KK, Singletary SE, Ames FC. Unusual aspects of breast cancer: case 3. Blue hives during lymphatic mapping for breast cancer. J Clin Oncol. 2001;19(9):2573-2574. doi: 10.1200/JCO.2001.19.9.2573

20. Krouse RS, Schwarz RE. Blue dye for sentinel lymph node mapping: not too sensitive, but too hypersensitive? Ann Surg Oncol. 2001;8(3):268-269. doi: 10.1007/s10434-001-0268-1
21. Sadiq TS, Burns WW III, Taber DJ, Damitz L, Ollila DW. Blue urticaria: a previously unreported adverse event associated with isosulfan blue. Arch Surg. 2001;136(12):1433-1435. doi: 10.1001/archsurg.136.12.1433

22. Kuerer HM, Wayne JD, Ross MI. Anaphylaxis during breast cancer lymphatic mapping. Surgery. 2001;129(1):119-120. doi: $10.1067 /$ msy.2001.111212

23. Giménez J, Botella-Estrada R, Hernández D, et al. Anaphylaxis after peritumoral injection of sulphan blue $1 \%$ for identification of the sentinel node in lymphatic mapping of the breast. Eur J Surg. 2001;167(12):921-923. doi: 10.1080/110241501753361622

24. Efron P, Knudsen E, Hirshorn S, Copeland EM. Anaphylactic reaction to isosulfan blue used for sentinel node biopsy: case report and literature review. Breast J. 2002;8(6):396-399. doi: 10.1046/j.1524-4741.2002.08614.x

25. Stefanutto TB, Shapiro WA, Wright PMC. Anaphylactic reaction to isosulphan blue. Br J Anaesth. 2002;89(3):527-528.

26. Sprung J, Tully MJ, Ziser A. Anaphylactic reactions to isosulfan blue dye during sentinel node lymphadenectomy for breast cancer. Anesth Analg. 2003;96(4):1051-1053. doi: 10.1213/01.ane.0000048709.61118.52

27. Raut CP, Daley MD, Hunt KK, et al. Anaphylactoid reactions to isosulfan blue dye during breast cancer lymphatic mapping in patients given preoperative prophylaxis. J Clin Oncol. 2004;22(3):567-568. doi: 10.1200/JCO.2004.99.276

28. Komenaka IK, Bauer VP, Schnabel FR, et al. Allergic reactions to isosulfan blue in sentinel lymph node mapping. Breast $\mathrm{J}$. 2005;11(1):70-72. doi: 10.1111/j.1075-122X.2005.21574.x

29. Saft $S$, Sarap M. Anaphylaxis during sentinel lymph node mapping. JAAPA. 2007;20(9):26-28. doi: 10.1097/01720610-200709000-00011

30. O'Sullivan MJ, Morrow M. Images in clinical medicine. Blue hives. N Engl J Med. 2008;358(6):e6. doi: $10.1056 / \mathrm{NEJMicm} 066872$

31. Cinar H, Koca B, Kesicioglu T, et al. Isosulfan blue-induced anaphylactic reaction during sentinel lymph node biopsy in breast cancer. Breast. 2012;21(2):220-222. doi: 10.1016/j.breast.2011.11.008

32. Reed $\mathrm{H}$, Shaw C, Rice M, Le HT. Isosulfan blue dye anaphylaxis presenting as impaired ability to ventilate via a laryngeal mask airway. A A Case Rep. 2014;3(1):1-2. doi: 10.1213/XAA.0000000000000036

33. Ortiz D, Alvikas J, Riker Al. A case of severe anaphylactic reaction secondary to isosulfan blue dye injection. Ochsner J. 2015;15(2):183-186.

34. Huang XY, Wu J, Liu ZB, et al. Application of methylene blue dye to sentinel lymph node biopsy in breast cancer and its influencing factors. Article in Chinese. Ai Zheng. 2007;26(10):1133-1137.

This article meets the Accreditation Council for Graduate Medical Education and the American Board of Medical Specialties Maintenance of Certification competencies for Patient Care and Medical Knowledge.

(02021 by the author(s); licensee Ochsner Journal, Ochsner Clinic Foundation, New Orleans, LA. This article is an open (c) (i) access article distributed under the terms and conditions of the Creative Commons Attribution (CC BY) license any medium, provided the original author(s) and source are credited. 